\title{
ISOLATION AND IDENTIFICATION OF BACTERIOCIN PRODUCING MICROBES USING BIOCHEMICAL AND MOLECULAR TOOLS AND ANALYSIS OF ITS BIOPRESERVATION POTENTIAL
}

\author{
PARMAR KESHRI NANDAN ${ }^{1}$, ANSHITA NAGAR ${ }^{2 *}$ \\ ${ }^{1}$ Department of Bioscience, Apeejay Stya University, Gurgaon, Haryana, India. ${ }^{2}$ Helix BioGenesis Pvt. Ltd., Noida, Uttar Pradesh, India. \\ Email: anshita.helix@gmail.com
}

Received: 04 September 2016, Revised and Accepted: 13 September 2016

\section{ABSTRACT}

Objective: Food safety is a matter of utmost importance in developing countries as well as in developed countries, so keeping this in mind this research work deals with the identification and characterization of bacteriocin producing microbes by using biochemical and molecular characterization. This study has also covered the biopreservation potential of bacteriocin produced by these microbes against sapodilla, tomato and banana as well.

Methods: For the purpose of sample collection and isolation, samples of milk, curd and gangajal water were taken and bacteriocin producing microbes were isolated by using serial dilution method. Screening of bacteriocin producing microbe was done by antibacterial sensitivity test using agar well diffusion method against Bacillus amyloliquefaciens, Escherichia Coli, Staphylococcus aureus and Pseudomonas aeruginosa by determining their zone of inhibition. Biochemical characterization was done by using different tests, such as, catalase test, mannitol test, citrate test, gelatin test, maltose test, indole test, urease test, lactose test etc. Molecular characterization was done by using $16 \mathrm{~S}$ rRNA gene sequencing. Preservative action of bacteriocin was observed on fruits that comprise sapodilla, tomato and banana by spraying bacteriocin on them and analyzing their activities shows for at least 10 days.

Results: Microbes were found to be Enterococcus faecalis (Accession number KX011874) and Bacillus cereus (Accession number KX011875). Periodic observatory studies reflect that using bacteriocin, banana can be preserved for nearly 6-7 days while sapodilla for 8-9 days and tomato for 9-10 days.

Conclusion: From present study we would like to conclude that bacteriocins produced by microbes which is found in milk or curd can also be used as biopreservatives for these defined fruits that is sapodilla, tomato and banana.

Keywords: Bacteriocin, Biopreservation, 16S rRNA analysis.

(C) 2016 The Authors. Published by Innovare Academic Sciences Pvt Ltd. This is an open access article under the CC BY license (http://creativecommons. org/licenses/by/4. 0/) DOI: http://dx.doi.org/10.22159/ajpcr.2016.v9s3.15043

\section{INTRODUCTION}

Many chemicals are being used for inactivation of foodborne pathogens so as to preserve food products for a longer duration [1]. Chemical preservatives have some of the undesirable side effects such as alteration in the constituents, nutritional, and organoleptic properties of the food and toxic effect on human health [1]. As far as the natural preservatives are concerned, they have shown a better alternative. Bacteriocin which is a natural product is isolated from milk, curd, cheese etc. can be used as a biopreservative. Bacteriocins are proteinaceous toxin produced by bacteria to inhibit the growth of similar or closely related bacteria [2]. It was first discovered by Gratia in 1925, when he was searching for ways to kill bacteria $[3,4]$. Bacteriocin is used as a preservative in food due to its heat stability, wider $\mathrm{pH}$ tolerance, and its proteolytic activity [5]. Due to thermostability and $\mathrm{pH}$ tolerance, it can withstand heat and acidity/alkalinity of food during storage condition [5]. Bacteriocins are commonly divided into three or four groups (Klaenhammer, 1993; Nes et al., 1996). Nisin was discovered in 1928 (Hurst, 1967) and subtilin, a nisin analog differing by 12 amino acid residues was discovered in 1948 (Hansen, 1993). Both belong to Class I, termed lantibiotics [6]. Bacteriocins of lactic acid bacteria are considered to be safe biopreservatives, since they are assumed to be degraded by the proteases in the gastrointestinal tract [6]. The aim of this study was to characterize the bacteriocin producing microbes and also to observe the biopreservation potential of bacteriocin producing microbes. Reported studies on Bacteriocin isolated from different sources are shown in the Table 1 and reported studies on preservative action of Bacteriocin are shown in Table 2. In the mean while this study also tried to find whether bacteriocin producing microbe is present in gangajal water or not.

\section{METHODS}

Source of sample collection

Samples of milk and curd were collected from a family in Sohna, Haryana, India. The sample of gangajal was collected from Haridwar, Uttarakhand, India.

\section{Bacterial strain}

Bacterial strain of Bacillus amyloliquefaciens, Staphylococcus aureus, Pseudomonas aeruginosa, and Escherichia coli was obtained from Helix BioGenesis Pvt. Ltd., Noida, Uttar Pradesh, India. They were subcultured freshly in Luria broth (LB media) and used further for research work.

\section{Isolation}

Samples were simultaneously inoculated to the LB and incubated at $37^{\circ} \mathrm{C}$ on continuous shaking at $150 \mathrm{rpm}$. After incubation, test tube was observed for the growth of bacteria. Serial dilution was done to know the bioburden of sample. Different colonies were isolated from LB agar plate after serial dilution from different samples. Isolated colonies were streaked onto freshly prepared LB agar. Pure cultures of these isolates were obtained by picking up the colonies. Glycerol stock was prepared to maintain the culture of isolates at $-80^{\circ} \mathrm{C}$.

\section{Screening of bacteriocin producing microbes}

Antibacterial sensitivity test (agar well diffusion method)

Antibacterial feature of bacteriocin against selected microorganisms (B. amyloliquefaciens, E. coli, S. aureus, and P. aeruginosa) were investigated by agar well-diffusion method. LB agar media were prepared and autoclaved at $121^{\circ} \mathrm{C}$ for 15 minutes at $15 \mathrm{lbs}$ 
and poured in sterile Petri plate up to a uniform thickness of approximately 10-15 minutes, and the agar was allowed to set at ambient temperature. This method is suitable for the organism to grow rapidly overnight at $35-37^{\circ} \mathrm{C}$. The wells were made in medium after inoculation with the microorganism. $200 \mathrm{ml}$ of inoculums were spread over LB agar plate using sterile spreader after few minutes 4 wells were made in each Petri plate and loaded with $100 \mathrm{ml}$ of isolates. Plates were incubated at $37^{\circ} \mathrm{C}$ for $24 \mathrm{hrs}$. Antibacterial activity was observed by measuring its zone of inhibition. The experiments were done in triplicate.

\section{Morphological and biochemical characterization of the bacteriocin producing isolates \\ Isolated colonies were characterized morphologically and biochemical test (Indole test, methyl red test, voges-proskauer test, citrate test, urease test, mannitol test, catalase test, starch hydrolysis, growth at $5 \% \mathrm{NaCl}$, growth at $10 \% \mathrm{NaCl}$, lactose test, maltose test, dextrose test, growth at $4{ }^{\circ} \mathrm{C}$ and gelatin test) were carried out to authenticate their identity by Cappuccino and Sherman, 1989.}

\section{Molecular characterization of bacteriocin producing microbes}

DNA was isolated by following standard methods (Sambrook et al. 1989), as modified by Baker et al., 1994 and 16S rDNA was amplified using the $16 \mathrm{~S}$ rDNA primers, F (5'-AGAGTTTGATCMTGGCTCAG-3') and $\mathrm{R}$ (5'-TACGGYTACCTTGTTACGACTT-3'). Polymerase chain reaction (PCR) was performed with $25 \mu \mathrm{l}$ reaction mix by taking $2.5 \mu \mathrm{l}$ of 10X Taq buffer, $15 \mathrm{mM} \mathrm{MgCl}, 1 \mu \mathrm{l}$ of dNTPs concentration, $1 \mu \mathrm{l}$ of reverse primer and $1 \mu \mathrm{l}$ of forward primer, $15.30 \mu \mathrm{l}$ of water, $4 \mu \mathrm{l}$ of DNA sample, and $0.2 \mu \mathrm{l}$ of Taq polymerase. PCR was subjected to 30 cycles (denaturation, 30 seconds at $95^{\circ} \mathrm{C}$; annealing, 30 seconds at $55^{\circ} \mathrm{C}$; extension, 1 minute at $72^{\circ} \mathrm{C}$ ) and 1 final extension cycle at $72^{\circ} \mathrm{C}$ for 10 minutes. PCR products were analyzed by agarose gel electrophoresis, which was performed using $1 \%$ agarose gel and EtBr was used to visualize DNA. 8-10 $\mu$ l of DNA sample was loaded in the wells and it was allowed to run at 70-80 V and analyzed under ultraviolet light.

\section{Biopreservative action of bacteriocin}

Biopreservative action of bacteriocin was observed on sapodilla, banana, and tomato. Bacteriocin isolates were sprayed on sapodilla, banana, and tomato and they were observed daily for their biopreservative action. The appearance of bacteriocin treated food products was compared with the control sample.

Table 1: Reported studies on Bacteriocin isolated from different sources

\begin{tabular}{|c|c|}
\hline Sl No. & Reported studies \\
\hline 1 & $\begin{array}{l}\text { Bacteriocin production by a new isolate of Lactobacillus } \\
\text { rhamnosus GPI under different culture conditions [7] }\end{array}$ \\
\hline \multirow[t]{3}{*}{2} & Purification and Characterization of a Bacteriocin \\
\hline & Produced by Lactobacillus lactis \\
\hline & Isolated from Marine Environment [8] \\
\hline 3 & $\begin{array}{l}\text { Production of bacteriocin like substances by lactic acid } \\
\text { bacteria isolated from regional ovine cheese [9] }\end{array}$ \\
\hline 4 & Isolation and characterization of nisin producing \\
\hline & Lactococcus lactis subsp. lactis from bean-sprouts [10] \\
\hline 5 & $\begin{array}{l}\text { Characteristics and genetic determinants of bacteriocin } \\
\text { activities produced by Carnobacterium piscicola isolated } \\
\text { from cheese [11] }\end{array}$ \\
\hline 6 & $\begin{array}{l}\text { Purification and characterization of bacteriocin produced } \\
\text { by Lactobacillus plantarum isolated from cow milk [12] }\end{array}$ \\
\hline 7 & $\begin{array}{l}\text { Characterization of bacteriocin produced by Lactobacillus } \\
\text { plantarum and Lactobacillus brevis [13] }\end{array}$ \\
\hline 8 & $\begin{array}{l}\text { Purification and characterization of bacteriocin Produced } \\
\text { by Lactobacillus brevis isolated from Dhulliachar: a } \\
\text { traditional food product of North East India [14] }\end{array}$ \\
\hline
\end{tabular}

\section{RESULTS}

\section{Isolation}

After inoculation of samples in LB broth, turbidity in LB broth was taken as a primary indicator for microbial growth. Nine morphologically different isolates were obtained from gangajal water, curd, and milk, whereas isolates 1 and 2 obtained from gangajal water, isolates $3,4,5$, and 6 from curd while isolates 7,8 , and 9 from milk.

\section{Antibacterial sensitivity test}

For identifying antibacterial sensitivity test, antibacterial activity was observed against B. amyloliquefaciens, E. coli, S. aureus, and $P$. aeruginosa by determining their zone of inhibition. Hence, in this study, isolates 2, 5 and 6 has not shown any antibacterial activity against B. amyloliquefaciens, whereas isolates 1, 3, 4, 7, 8, and 9 has shown antibacterial activity against the same. As far as E. coli was concerned isolates 1,3 , and 6 has not shown any inhibition, whereas $E$. coli found to be inhibited by isolates $2,4,5,7,8$, and 9 as given in Table 1 . Isolate 4 and 9 were selected for $16 \mathrm{~S}$ rRNA gene sequence analysis as these two samples were showing better result for well diffusion method compared to other isolates. Antibacterial activity of bacteriocin in isolates 3 and 4 is shown in Fig. 1 and zone of inhibition for antibacterial activity is shown in Table 3.

\section{Morphological and biochemical characterization}

From this study, nine different isolates were morphologically characterized by Gram-staining and it has shown in the presence of Gram-positive bacteria with rod shape in its isolates 1 and 4 while cocci shape in isolates 2,5 , and 9, whereas Gram-negative bacteria with rod shape found to be present in isolates $3,6,7$, and 8. Biochemical characterization has revealed the presence of methyl red in isolates $1,3,4,7$, and 9, whereas absent in isolates 2,5 , and 8. Voges-proskauer was present in isolates $1,3,4,5,7$, and 9 while absent in isolates 2,6 , and 8 . Indole was found to be absent in all

\section{Table 2: Reported studies on preservative action of Bacteriocin}

\begin{tabular}{|c|c|}
\hline Sl No. & Reported studies \\
\hline 1 & $\begin{array}{l}\text { Biochemical and Genetic Characterization of Enterocin } \\
\text { P, a Novel sec-Dependent Bacteriocin from Enterococcus } \\
\text { faecium P13 with a Broad Antimicrobial Spectrum [15] }\end{array}$ \\
\hline 2 & $\begin{array}{l}\text { The use of the bacteriocin, nisin, as a preservative in } \\
\text { ricottatype cheeses to control the foodborne pathogen } \\
\text { Listeria monocytogenes [16] }\end{array}$ \\
\hline 3 & $\begin{array}{l}\text { Evidence for a bacteriocin like substance produced by a } \\
\text { new strain of Streptococcus sp., inhibitory to gram positive } \\
\text { Food-borne pathogens [17] }\end{array}$ \\
\hline 4 & $\begin{array}{l}\text { Effective use of nisin to control lactic acid bacterial } \\
\text { spoilage in vacuum-packed } \\
\text { Bologna-type sausage [18] }\end{array}$ \\
\hline 5 & $\begin{array}{l}\text { Applications of bacteriocins in food, livestock health and } \\
\text { medicine [19] }\end{array}$ \\
\hline 6 & $\begin{array}{l}\text { Application of bacteriocins in vegetable food } \\
\text { biopreservation [20] }\end{array}$ \\
\hline 7 & $\begin{array}{l}\text { Isolation of a Lactobacillus salivarius Strain and } \\
\text { Purification of its Bacteriocin, which is inhibitory to } \\
\text { Campylobacter jejuni in the Chicken Gastrointestinal } \\
\text { System [21] }\end{array}$ \\
\hline 8 & $\begin{array}{l}\text { Application of Lactic Acid Bacteria and their bacteriocins } \\
\text { for food Biopreservation [22] }\end{array}$ \\
\hline 9 & $\begin{array}{l}\text { Application of the broadspectrum bacteriocin enterocin } \\
\text { AS- } 48 \text { to inhibit Bacillus coagulans in canned fruit and } \\
\text { vegetable foods [23] }\end{array}$ \\
\hline 10 & $\begin{array}{l}\text { Potential of antagonistic microorganisms and bacteriocins } \\
\text { for the biological preservation of foods [24] }\end{array}$ \\
\hline 11 & $\begin{array}{l}\text { Class IIa bacteriocins: biosynthesis, structure and } \\
\text { activity [25] }\end{array}$ \\
\hline 12 & $\begin{array}{l}\text { Antibiotic and Bacteriocin Sensitivity of Listeria } \\
\text { monocytogenes strains isolated from different foods [26] }\end{array}$ \\
\hline
\end{tabular}


isolates. Citrate was found be present only in isolate 2 . Urease was found to be present in isolates 6 and 8 and absent in other isolates. Mannitol was found to be absent in all isolates. Catalase was found to be present in isolates $2,3,4,5,6$, and 8 while absent in isolates 1,7 , and 9. Starch hydrolysis was found in isolates 4 and 5. Growth at $5 \% \mathrm{NaCl}$ was found in isolates $1,3,4$, and 5 . Growth at $10 \% \mathrm{NaCl}$ was not found in any isolates. Gelatin was found to be absent in all isolates. Lactose was found to be present in isolate 8 while absent in other isolates. Maltose was found to be present in isolates 1 , 3,7 , and 9 while absent in isolates $2,4,5,6$, and 8. Dextrose was found to be present in isolates $1,2,3,5,6,7,8$, and 9 while absent in isolate 4 . Growth at $4^{\circ} \mathrm{C}$ was not found in any isolates. Biochemical characterization for nine isolates is shown in Table 4.

\section{Molecular characterization}

Using 16S rRNA gene sequence analysis Gram-positive bacterium isolate 4 and 9 were identified, their sequences have been submitted to the National Center for Biotechnology Information GeneBank and their accession number has been achieved. Isolate 4 found to be Bacillus cereus (Accession number KX011875) and isolate 9 found to be Enterococcus faecalis (Accession number KX011874).

Using phylogeny.fr (http://www.phylogeny.fr/simple_phylogeny.cgi), phylogenetic tree was formed as shown in Figs. 2 and 3.

\section{Biopreservative action of bacteriocin}

Biopreservation activity for isolates 4 and 9 was done on fruit samples sapodilla, banana, and tomato. Fruit samples were sprayed with bacteriocin, and these were checked periodically for 10 days. Test samples were regularly compared with control. These periodic observatory studies reflect that using bacteriocin, banana can be preserved for nearly 6-7 days while sapodilla for 8-9 days and tomato for 9-10 days. Biopreservative action of bacteriocin for different fruits is shown in Table 5.

\section{DISCUSSION}

Our result suggested that bacteriocins producing E. faecalis (Accession number KX011874) and Bacillus cereus (Accession number KX011875) naturally occur and survive in milk and curd, respectively. The present study has shown the significant applications of bacteriocin (isolated from Bacillus cereus and E. faecalis) as a biopreservative by applying on tomato, banana, and sapodilla as well. This research has clearly shown the comparative analysis between the control and test sample through observatory studies. An earlier study has been done on strains producing bacteriocins such as Enterococcus mundtii (Bennik et al., 1998), Lactobacillus lactis subsp. cremoris $\mathrm{R}$ (Yildirim and Johnson, 1998), Lactobacillus bavaricus (bavA) (Larsen et al., 1993), Carnobacterium piscicola CP5 (Herbin et al., 1997), etc. Apart from

Table 3: Antibacterial activity of bacteriocin

\begin{tabular}{|c|c|c|c|c|}
\hline Isolates & $\begin{array}{l}\text { Bacillus amyloliquefaciens } \\
\text { (Zone of inhibition) }\end{array}$ & $\begin{array}{l}\text { Escherichia coli } \\
\text { (Zone of inhibition) }\end{array}$ & $\begin{array}{l}\text { Staphylococcus aureus } \\
\text { (Zone of inhibition) }\end{array}$ & $\begin{array}{l}\text { Pseudomonas aeruginosa } \\
\text { (Zone of inhibition) }\end{array}$ \\
\hline 1 & $0.013 \mathrm{~m}$ & 0 & 0 & 0 \\
\hline 2 & 0 & $0.015 \mathrm{~m}$ & 0 & 0 \\
\hline 3 & $0.032 \mathrm{~m}$ & 0 & $0.015 \mathrm{~m}$ & 0 \\
\hline 4 & $0.021 \mathrm{~m}$ & $0.015 \mathrm{~m}$ & $0.015 \mathrm{~m}$ & $0.031 \mathrm{~m}$ \\
\hline 5 & 0 & $0.013 \mathrm{~m}$ & $0.018 \mathrm{~m}$ & 0 \\
\hline 6 & 0 & 0 & 0 & $0.018 \mathrm{~m}$ \\
\hline 8 & $0.015 \mathrm{~m}$ & $0.013 \mathrm{~m}$ & 0 & $0.012 \mathrm{~m}$ \\
\hline 9 & $0.017 \mathrm{~m}$ & $0.018 \mathrm{~m}$ & 0 & $0.016 \mathrm{~m}$ \\
\hline
\end{tabular}

Table 4: Biochemical characterization

\begin{tabular}{|c|c|c|c|c|c|c|c|c|c|}
\hline Tests & $\begin{array}{l}\text { Isolate } \\
1\end{array}$ & $\begin{array}{l}\text { Isolate } \\
2\end{array}$ & $\begin{array}{l}\text { Isolate } \\
3\end{array}$ & $\begin{array}{l}\text { Isolate } \\
4\end{array}$ & $\begin{array}{l}\text { Isolate } \\
5\end{array}$ & $\begin{array}{l}\text { Isolate } \\
6\end{array}$ & $\begin{array}{l}\text { Isolate } \\
7\end{array}$ & $\begin{array}{l}\text { Isolate } \\
8\end{array}$ & $\begin{array}{l}\text { Isolate } \\
9\end{array}$ \\
\hline Indole test & Negative & Negative & Negative & Negative & Negative & Negative & Negative & Negative & Negative \\
\hline MR test & Positive & Negative & Positive & Positive & Negative & Positive & Positive & Negative & Positive \\
\hline VP test & Positive & Negative & Positive & Positive & Positive & Negative & Positive & Negative & Positive \\
\hline Citrate test & Negative & Positive & Negative & Negative & Negative & Negative & Negative & Negative & Negative \\
\hline Urease test & Negative & Negative & Negative & Negative & Negative & Positive & Negative & Positive & Negative \\
\hline Mannitol test & Negative & Negative & Negative & Negative & Negative & Negative & Negative & Negative & Negative \\
\hline Starch hydrolysis & Negative & Negative & Negative & Positive & Positive & Negative & Negative & Negative & Negative \\
\hline Growth at $5 \% \mathrm{NaCl}$ & Positive & Negative & Positive & Positive & Positive & Negative & Negative & Negative & Negative \\
\hline Growth at $10 \% \mathrm{NaCl}$ & Negative & Negative & Negative & Negative & Negative & Negative & Negative & Negative & Negative \\
\hline Lactose test & Negative & Negative & Negative & Negative & Negative & Negative & Negative & Positive & Negative \\
\hline Maltose test & Positive & Negative & Positive & Negative & Negative & Negative & Positive & Negative & Positive \\
\hline Dextrose test & Positive & Positive & Positive & Negative & Positive & Positive & Positive & Positive & Positive \\
\hline Growth at $4^{\circ} \mathrm{C}$ & Negative & Negative & Negative & Negative & Negative & Negative & Negative & Negative & Negative \\
\hline Gelatin test & Negative & Negative & Negative & Negative & Negative & Negative & Negative & Negative & Negative \\
\hline
\end{tabular}

Table 5: Biopreservative action of bacteriocin for different fruits

\begin{tabular}{llll}
\hline Days & Banana & Sapodilla & Tomato \\
\hline $1^{\text {st }}$ day & Appeared fresh & Appeared fresh & Appeared fresh \\
$4^{\text {th }}$ day & Appeared fresh & Appeared fresh & Appeared fresh \\
$6^{\text {th }}$ day & Spoiled up to some extent & Appeared fresh & Appeared fresh \\
$8^{\text {th }}$ day & Started to spoil rapidly & Spoiled up to some extent & Spoiled up to some extent \\
\hline
\end{tabular}




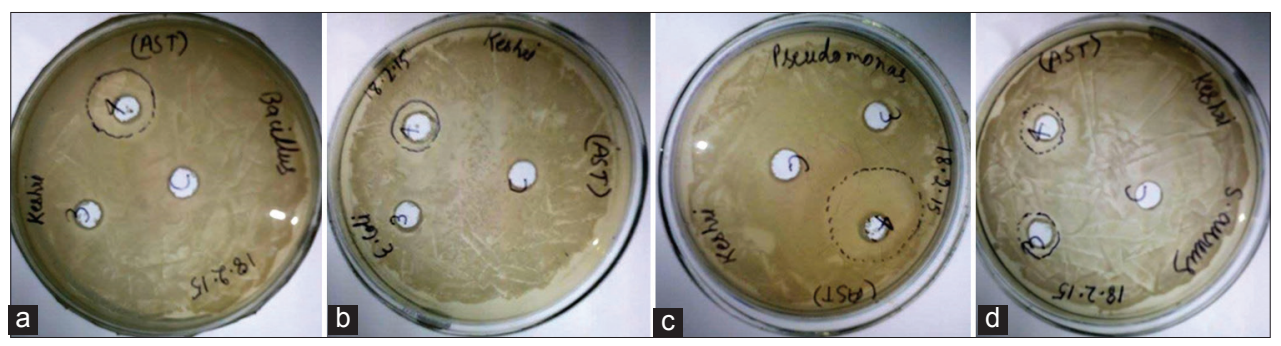

Fig. 1: Antibacterial activity of bacteriocin in isolates 3 and 4 against (a) Bacillus amyloliquefaciens, (b) Escherichia coli, (c) Staphylococcus aureus, and (d) Pseudomonas aeruginosa

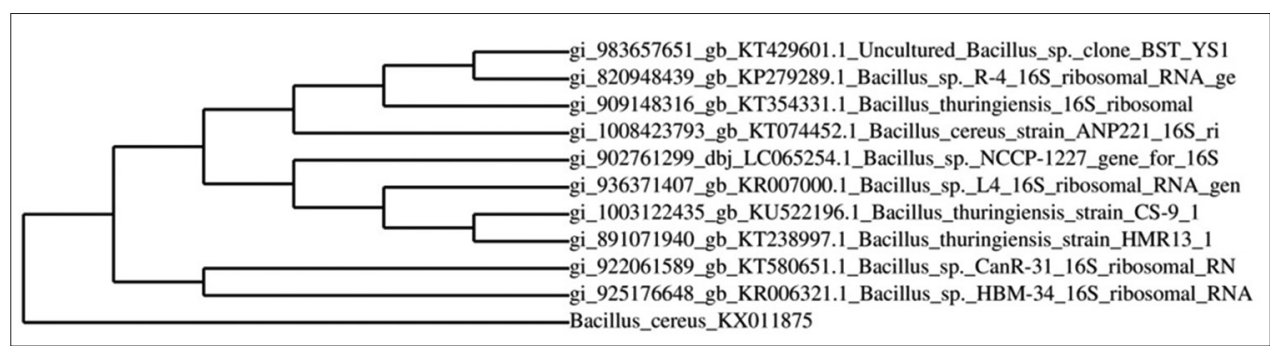

Fig. 2: Neighbor-joining phylogenetic tree based on 16S rRNA gene sequence of Bacillus cereus KX011875

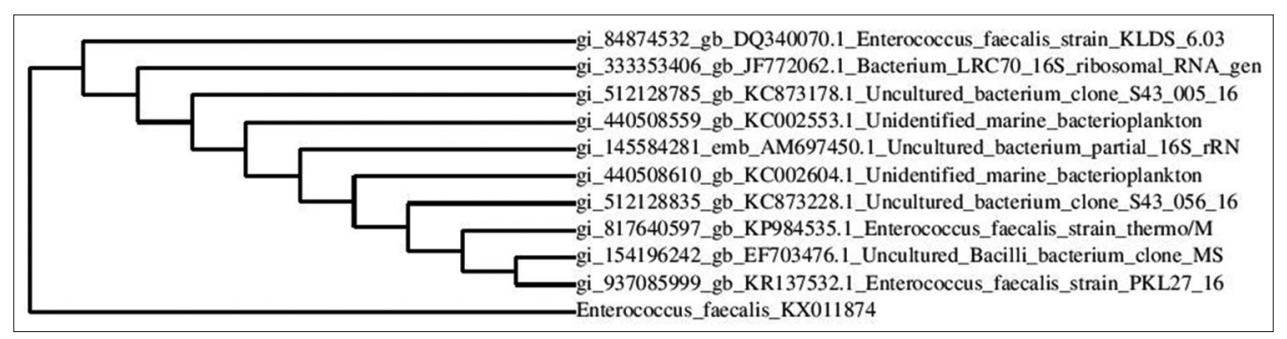

Fig. 3: Neighbor-joining phylogenetic tree based on 16 S rRNA gene sequence of Enterococcus faecalis KX011874

studying on isolates from milk and curd, this paper also tried to study on isolates from gangajal water as well, to find whether the bacteriocin producing microbes are present in gangajal or not, although gangajal was not having the bacteriocin producing microbe, so far, no such study on gangajal water has been done in the past. This study would surely provide a preliminary foundation for further studies in exploring the other probable outcomes and applications of bacteriocin.

\section{CONCLUSION}

This research work has properly characterized and identified the bacteriocin producing microbes on the basis of biochemical and molecular characterization. It has also been shown that bacteriocin treated food products can stay fresh for a longer period. So, it demonstrates the effectiveness of the preservative action of bacteriocin. Thus, bacteriocin can be suggested to be used as a safe, natural, and effective biopreservative.

\section{ACKNOWLEDGMENT}

The authors are highly thankful to Neelam Bhola and Dimple Sharma, Research Associate, Helix BioGenesis Pvt. Ltd., Noida, India and Yash Sharma, Amity Institute of Biotechnology, Amity University, Noida, Uttar Pradesh, India for their continuous support and guidance.

\section{REFERENCES}

1. Bali V, Panesar PS, Bera MB. Isolation, screening and evaluation of antimicrobial activity of potential bacteriocin producing lactic acid bacteria isolate. Microbiol J 2011:1(3);113-9.

2. Deshmukh PV, Thorat PR. Bacteriocins: A new trend in antimicrobial food packaging. Int J Adv Res Eng Appl Sci 2013;2(1):1-2.
3. Gratia A. A remarkable example of antagonism between two strains of E. coli. Compt Rend Soc Biol 1925;93:1040-2.

4. Gratia JP. André Gratia: A forerunner in microbial and viral genetics. Genetics 2000;156(2):471-6.

5. Gautam N, Sharma N. Bacteriocin: Safest approach to preserve food products. Indian J Microbiol 2009;49(3):204-11.

6. Cleveland J, Montville TJ, Nes IF, Chikindas ML. Bacteriocins: Safe, natural antimicrobials for food preservation. Int J Food Microbiol 2001;71(1):1-20.

7. Sarika AR, Lipton AP, Aishwarya MS. Bacteriocin production by a new isolate of Lactobacillus rhamnosus GPI under different culture conditions. Adv J Food Sci Technol 2010;2(5):291-7.

8. Rajaram G, Manivasagam P, Thilagavathi B, Saravanakumar A. Purification and characterization of a bacteriocin produced by Lactobacillus lactis isolated from marine environment. Adv J Food Sci Technol 2010;2(2):138-44.

9. Nespolo CR, Brandelli A. Production of bacteriocin-like substances by lactic acid bacteria isolated from regional ovine cheese. Braz J Microbiol 2010;41(4):1009-18.

10. Cai Y, Ng LK, Farber JM. Isolation and characterization of nisinproducing Lactococcus lactis subsp. lactis from bean-sprouts. J Appl Microbiol 1997;83(4):499-507.

11. Herbin S, Mathieu F, Brulé F, Branlant C, Lefebvre G, Lebrihi A. Characteristics and genetic determinants of bacteriocin activities produced by Carnobacterium piscicola CP5 isolated from cheese. Curr Microbiol 1997;35(6):319-26.

12. Sankar NR, Priyanka VD, Reddy PS, Rajanikanth P, Kumar VK, Indira M. Purification and characterization of bacteriocin produced by Lactobacillus plantarum isolated from cow milk. Int J Microbiol Res 2012;3(2):133-7.

13. Ogunbanwo ST, Sanni AI, and Onilude AA. Characterization of bacteriocin produced by Lactobacillus plantarum $\mathrm{F} 1$ and Lactobacillus brevis OG1. Afr J Biotechnol 2003;2(8):219-27. 
14. Gautam N, Sharma N, Ahlawat OP. Purification and characterization of bacteriocin produced by Lactobacillus brevis UN Isolated from Dhulliachar: A traditional food product of North East India. Indian J Microbiol 2014;54(2):185-9.

15. Cintas LM, Casaus $\mathrm{P}$, Håvarstein LS, Hernández PE, Nes IF Biochemical and genetic characterization of enterocin $P$, a novel secdependent bacteriocin from Enterococcus faecium P13 with a broad antimicrobial spectrum. Appl Environ Microbiol 1997;63(11):4321-30.

16. Davies EA, Bevis HE, Delves-Broughton J. The use of the bacteriocin, nisin, as a preservative in ricotta-type cheeses to control the foodborne pathogen Listeria monocytogenes. Lett Appl Microbiol 1997;24(5):343-6.

17. Gomez S, Cosson C, Deschamps AM. Evidence for a bacteriocinlike substance produced by a new strain of Streptococcus sp. inhibitory to gram-positive food-borne pathogens. Res Microbiol 1997;148(9):757-66.

18. Davies EA, Milne CF, Bevis HE, Potter RW, Harris JM, Williams GC et al. Effective use of nisin to control lactic acid bacterial spoilage in vacuum-packed bologna-type sausage. J Food Prot 1999;62(9):1004-10.

19. Bemena LD, Mohamed LA, Fernandes AM, Lee BH. Applications of bacteriocins in food, livestock health and medicine. Int J Curr Microbiol Appl Sci 2014;3(12):924-49

20. Settanni L, Corsetti A. Application of bacteriocins in vegetable food biopreservation. Int J Food Microbiol 2008;121(2):123-38

21. Stern NJ, Svetoch EA, Eruslanov BV, Perelygin VV, Mitsevich EV, Mitsevich IP, et al. Isolation of a Lactobacillus salivarius strain and purification of its bacteriocin, which is inhibitory to Campylobacter jejuni in the chicken gastrointestinal system. Antimicrob Agents Chemother 2006;50(9):3111-6.

22. Gálvez A, López RL, Pulido RP, Burgos MJ. Application of lactic acid bacteria and their bacteriocins for food biopreservation. Food Biopreservation Springer Briefs in Food, Health, and Nutrition. New York: Springer-Verlag; 2014. p. 15-22.

23. Lucas R, Grande MA, Abriouel H, Maqueda M, Ben Omar N, Valdivia E, et al. Application of the broad-spectrum bacteriocin enterocin AS-48 to inhibit Bacillus coagulans in canned fruit and vegetable foods. Food Chem Toxicol 2006;44(10):1774-81.

24. Schillinger U, Geisen R, Holzapfel WH. Potential of antagonistic microorganisms and bacteriocins for the biological preservation of foods. Trends Food Sci Technol 1996;7:158-64.

25. Ennahar S, Sashihara T, Sonomoto K, Ishizaki A. Class IIa bacteriocins: Biosynthesis, structure and activity. FEMS Microbiol Rev 2000:24(1):85-106

26. Kocan EG, Cosansu S, Ayhan K, Juneja VK, Materon L. Antibiotic and bacteriocin sensitivity of Listeria monocytogenes strains isolated from different foods. Food Nutr Sci 2012:3;363-8. 